\title{
Transatlantica
}

Revue d'études américaines. American Studies Journal

$2 \mid 2011$

Sport et société / Animals and the American

Imagination

\section{The American Jockey, 1865-1910}

\section{Steven A. Riess}

\section{(2) OpenEdition}

Journals

Édition électronique

URL : https://journals.openedition.org/transatlantica/5480

DOI : $10.4000 /$ transatlantica.5480

ISSN : 1765-2766

Éditeur

Association française d'Etudes Américaines (AFEA)

Référence électronique

Steven A. Riess, «The American Jockey, 1865-1910», Transatlantica [En ligne], 2 | 2011, mis en ligne le 16 juin 2012, consulté le 31 janvier 2023. URL : http://journals.openedition.org/transatlantica/5480 ;

DOI : https://doi.org/10.4000/transatlantica.5480

Ce document a été généré automatiquement le 31 janvier 2023.

\section{(c) $($ ) $(9)$}

Creative Commons - Attribution - Pas d'Utilisation Commerciale - Pas de Modification 4.0 International - CC BY-NC-ND 4.0

https://creativecommons.org/licenses/by-nc-nd/4.0/ 


\title{
The American Jockey, 1865-1910
}

\author{
Steven A. Riess
}

1 Scholars have largely neglected the history of thoroughbred racing in the United States even though it was among the most important American sports. Furthermore, horseracing was the first major sport in the American colonies, with racecourses in New York, Charles Town, Annapolis and Williamsburg by the mid-eighteenth century, even before the introduction of the thoroughbred to North America. The Sport of Kings drew estimated crowds in excess of 50,000 in the ante-bellum era, long before baseball or football had developed, and decades prior to the Marquis of Queensberry boxing rules. The sport struggled in the North by the 1840s, though it remained a major spectatorial event in the southern states. Then following the Civil War, racing boomed in the North, particularly in New York City, the site of such elite courses as Jerome Park, Sheepshead Bay, and Belmont Park. Prestigious jockey clubs ran those tracks, because they wanted to "improve the breed," but mainly because they enjoyed gambling, the sociability at the tracks' elegant clubhouses, and the status membership provided. The sport became so popular that entrepreneurs established proprietary tracks to make money from the sale of admission tickets, the profits from concessions, and their share of fees charged bookmakers to facilitate gambling among spectators (Hervey, 1944; Vosburgh, 1922; Robertson, 1964; Adelman, 1986; Somers, 1972).

2 As recently as the 1950s and 1960s, horseracing was the number one spectator sport in the United States. However, horse racing in the United States is currently struggling to survive due to international competition for the finest horses, but especially from competition for the gambling dollar from government-sponsored lotteries, legalized betting parlors, including sports wagering, computer gaming, and illegal enterprises.

3 Historians of sport have given enormous attention to the careers of professional athletes. There is an extensive literature on professional baseball players, prizefighters, football players, and basketball players. In my own research, I studied sport as an avenue of social mobility. I found that only about one-third of major league baseball players active in the late nineteenth century ( 35.6 percent) came from blue-collar origins. Then in the early twentieth the proportion of blue-collar players was still about one-third (34.4 percent) at a time when a remarkable one-fourth ( 25.8 percent) of 
major leaguers had attended college. Few of these players moved into the upper class after retirement, but about four-fifths of players throughout the twentieth century ended up with white-collar or farming positions. I also generated cohorts of professional football players active in the 1920-1980s, and found that until the 1950s, they mostly came from white-collar backgrounds. They not only attended college, but from the 1930s through the 1950s, most graduated, and 95 percent went on to whitecollar jobs. Basketball players were the most urban of all the athletes in professional team sports, but were much more likely to come from working class backgrounds. They relied on their athletic skill to get them college scholarships, and typically went on to graduate. Their high graduation rate reflected basketball's minor status as a professional sport until the 1960s, and these athletes knew they had to prepare for another career. Boxers, not surprisingly, were nearly all drawn form the inner city, and were the poorest and least educated of all pro athletes. They were men who had few if any alternative options to get ahead. Champions and contenders made a lot of money, but spent it freely, and did not prepare for retirement. Even world-class fighters ended up pretty much back where they started out (Riess, 1999, 166, 176, 203; Riess, 1991, 229-33, 240-42; Riess, 1990, 83-117; Riess, 1980, 235-50).

4 However, historians have not thoroughly studied the occupation of jockey, a job that goes back to colonial America, when the first jockeys were slaves. In the ante-bellum South, the main center of racing, riders were still mainly slaves, like the well-known "Monkey" Simon, while in the North, owners used Englishmen or local whites. The jockeys were not well known or highly remunerated. Racing accounts seldom mentioned the riders, unless they were hurt or their "carelessness or criminality" caused an upset (Hotaling, 1999, 1-173; New Orleans Times, April 9, 1871, cited in Somers, $111)$.

5 The conventional wisdom among bettors was that the best horse won regardless of the rider. However, by the 1880s, this philosophy drastically changed. Jockeys were no longer just along for the ride, but owners and fans alike recognized them for their skill, courage, and savvy as they guided, eased, and prodded their mounts to the winner's circle. Bettors increasingly chose their bets by the jockeys as much as the horses. In New Orleans in the early 1880s, tracks began to post the names of jockeys together with the horses at the pool stands because some gamblers got more business if their clients knew the rider. In 1885, the New Orleans' Fair Grounds recognized the role of jockeys by awarding a medal to the top rider at its meet. Jockeys in this era were the highest paid athletes in North America, with the finest riders making incomes in excess of $\$ 10,000$ (Trenton Daily True American, 4 June 1890; Somers, 111-12).

6 In this study of American jockeys, I have not been able to generate the quantitative data necessary to produce a collective report on jockeys, and will focus instead on qualitative data to produce a picture of this occupation. My focus will be less on social mobility, than on the lives, careers, and races of the elite jockeys who dominated their peers in the years right after the Civil War when racing boomed in the North, until the early twentieth century when American racing was in dire straits. At one time, there were 314 racetracks in North America, but by 1910, there were only a handful in Maryland, Kentucky, and Canada. The key issues will be the remaking of a black dominated occupation into an all-white one, and the internationalization of the American jockey as they tried to break into the sport in England. 


\section{The Work of the Jockey}

7 The daily life and work of a jockey was extremely arduous and dangerous. No other athletes endured such physical and mental tortures, requiring extreme privation to make weight. They started the day by exercising horses before breakfast. They exercise to keep down weight, working out at a gym attached to the track or putting on two suites of heavy underwear, two heavy sweaters and run of four or five miles. They have lunch at noon and by 1 PM get ready for the day's racing. At 1:30 they go to get weighed in, and then to the post. The valet helps him mount and give him his whip. Winning riders got at least $\$ 20$ ("Successful Jockeys Reach the Top by Hard Work and Energy"). Jockeys, like prizefighters, were reputedly born, not made:

A man must be born to the saddle. If he is he will show it in the first time he jumps into the pigskin when a boy. A lad who is a born jockey can ride as easily and as naturally at the first clip as he if had been in the saddle all his life. He feels perfectly at home on the horse and never gets afraid no matter how swift may be the pace the annual strikes or how spirited he may be. The horse and boy are one, and move as one ("Hard Work of a Jockey").

8 The job required recklessness. As the Police Gazette pointed out, "When a boy becomes possessed of common sense he ceases to be a star rider."

In no other calling in the world, perhaps, is a preponderance of recklessness so necessary or valuable as in the race rider's. [...] Absence of recklessness does not necessarily mean absence of nerve. Men may have plenty of nerve and yet be without a particle of recklessness, although in racing parlance the two things mean about the same. Once a boy refused to "take a chance" and squeeze into a hole near the rail, thereby losing what might prove of inestimable advantage, straightway the impression goes aboard that he had lost his nerve, when he has merely exercised what would be considered pretty good common sense on the part of a man claiming to be possessed of that commodity. And hence it seems to be pretty generally understood among horsemen that when a boy "gets old enough to have sense" he is too old to be a star rider. ("Great Nerve Required in Many Cases by Winning Jockeys").

Jockeys were under pressure to win at almost any cost. Riders were expected by owners and trainers to employ the whip, though a few top riders like Jimmy McLaughlin relied heavily on just their hands and heels to push his horses. Critics felt that whipping was overdone, although the press invariably condemned any jockey who did not use the whip as "sleepy, careless, and, at times, worse" (Spirit of the Times 120, 23 Aug. 1890, 190).

While whipping was unavoidable, such artificial methods as drugs given by trainers or electrical stimulants were not permitted. Electric prods powered from a battery worn as a belt brought startling results to old horses. The proscription on electrical devices was very successful but drugs, less so (Chicago Daily News, 17 Dec. 1895, 6).

11 Foul racing was decried because it led to dangerous accidents. There were instances of interference with competitors that resulted in deaths. In 1900, at Chicago's Washington Park, Pike Barnes saw a rider trying to come from the rear to pass him, so he crossed over and blocked his competition. The horses collided, and a rider fell and was killed (Trevathan, 1900).

12 Quick wealth and fame that came to uneducated, unsophisticated young jockeys was often more than they could handle. The Spirit noted, "they speedily come to believe that they are immense powers in the racing world. Backers and admirers shower them with presents, and money seems to them as common as dirt." They became 
conspicuous consumers who eagerly showed off their wealth with fancy clothes and expensive possessions. They soon found it increasingly difficult to maintain selfdiscipline to keep fit and sustain their mental toughness, and easier to think they were smarter than their trainers were ("A Jockey Ring in England").

\section{African American Jockeys}

13 There were at least 117 African American jockeys after the Civil War. They had a very high reputation for honesty and integrity. As one newspaper asserted in 1890, "they know that in the skill of their hands and in the alertness of their brains and eyes rests many a time the fate of fortunes, and they seldom abuse the confidence placed in them." (Ashe 125; Trenton Daily True American, June 4, 1890, 3). As the Spirit attested, "The best riding talent is by no means confined to the white race [...]. In the colored ranks are to be found jockeys of the most sterling honesty and integrity, and it is unfortunate that the same cannot be said of all white jockeys" ("All the Best Jockeys of the West are Colored").

14 When Saratoga track opened on a permanent basis in 1865, half of the jockeys were African Americans, most notably Abe Hawkins, a former slave. Experts rated him the second best known American athlete of the day, second only to the white jockey Gilpatrick. Paradoxically, the jockey club barred African Americans from the grandstand. He won the Travers and the first Jerome Handicap. He raced as a free man from 1864 to 1867, having won twenty-five races when he died from tuberculosis (Hotaling, 1999, 143-50, 179-207; Hotaling, 1995, 46, 66-67).

In 1870, the twenty-year old Edward Dudley Brown became the first African American to win the prestigious Belmont Stakes aboard Kingfisher. He started out riding as a slave when he learned to groom and train horses for his owner Robert A. Alexander, and continued to work for him after emancipation until Alexander died in 1867. Brown's racing career was shortened by weight problems, and in 1874, he became a full-time trainer. He trained horses for over thirty years, and his triumphs included the 1877 Kentucky Derby. Brown also established his own stable in the late nineteenth century, winning the Kentucky Oaks $(1893,1900)$. Two colts he trained, and later sold, won the Kentucky Derby. Brown was elected to the Racing Hall of Fame in 1984 (Hotaling, 1999, 209-11; 332-33; Reilly).

Black jockeys first earned considerable prominence at southern tracks. At the inaugural Kentucky Derby in 1875, won by Oliver Lewis on Aristides, 14 of 15 jockeys were African Americans. Black riders won 15 of the first 28 Derbies. Blacks rode regularly in New Orleans at Metairie and the Fair Grounds without any apparent incidents. As late as 1893 the top jockey at the Fair Grounds was a mulatto named Sargent (Hotaling, 1999, 230-31; Somers, 112-13).

Black jockeys soon achieved enormous success in the North. An article in the New York Herald in 1889 was entitled, "Colored Jockeys Show the Way." The sportswriter reported that on September 19, all six races at Brooklyn's Gravesend were won by African Americans:

If a composite photograph had been made of the jockeys who rode the six winners at Gravesend, it would have been as black as Erebus. There wouldn't have been a single light line in it, unless the camera happened to catch Hamilton with his mouth 
wide open displaying the pearly white teeth which form the only relieving feature of his coal black face (20 Sept.1889, cited in Sugar and Richardson, 113). United States was Isaac Burns Murphy. According to L.P. Tarelton, the former owner of the Fleetwood Stables, "I have seen all the great jockeys of England and this country for years back, but all in all Isaac Murphy is the greatest of them all." (136). Son of a bricklayer who fought with the union army, Murphy started racing at 12 under his given name of Isaac Burns. He soon became known as the "colored Archer," after the great British rider Fred Archer. By 1882 he was earning \$20,000 a year, including a $\$ 10,000$ retainer from horseman Lucky Baldwin, retainer fees from other leading horsemen like Ed Corrigan and James Ben Ali Haggin, plus \$25 for winning any race and $\$ 15$ for losing. In 1884, Murphy won the first American Derby in Chicago and captured three more American Derbies in the next four years. Murphy won his first Kentucky Derby in 1884, and was the first to win two straight Kentucky Derbies in 1891 and 1892 (Wiggins 21-33; Trenton Daily True American, 4 June 1890; Hotaling, 1999, 239-75).

Murphy claimed to have won 44 percent of his races $(628$ out of 1,412$)$, although a recent review puts the record at 34 percent (530 out of 1,538), still an outstanding achievement. Murphy earned $\$ 250,000$ over his career, leaving at least $\$ 30,000$ when he died of pneumonia in 1896 at the age of thirty-five. Murphy's early demise was possibly a product of his constant efforts to keep off weight through crash dieting, sweat baths, and intense exercising (Hotaling, 1999, 272). When Murphy, West or Tony Hamilton was substituted for some other jockey, the betting odds tumbled (Spirit of the Times, 113, June 25, 1887, 729; "All the Best Jockeys of the West are Colored").

20 Another top black rider was Pinkey Barnes, one of the smallest jockeys. In 1890 he rode for Lucky Baldwin getting $\$ 8,000$ a year, and with outside mounts, his total income was estimated at $\$ 12,000-15,000$. One paper noted, "He is the most sensational rider on the American turf [...]. He is the youngest first class rider, and especially valuable for his ability to drop weight. He is a great judge of pace and his finishes are equal to Garrison" (Trenton Daily True American, 4 June 1890).

21 Black jockeys played a leading role at the elite eastern tracks in the 1890s, including Tony Hamilton who was the fourth winningest rider in the United States, including in 1891 the \$67,675 Brooklyn Futurity. The following year, Hamilton was the second leading jockey in America (Spirit of the Times 112, 8 Jan. 1887, 738).

Edward Hotaling, the preeminent historian of black jockeys, rates Willie Simms even higher than Hamilton, and on a par with white rider Fred Taral as the best jockeys of the 1890s. Simms won 25 percent of his career races and Simms led the nation in victories with 182 in 1893 and repeated in 1894. Pierre Lorillard paid him \$10,500 for first call on his services. In 1895 he worked for Mike and Phil Dwyer, and Tammany boss Richard Croker, and earned over \$20,000. During his career he won two Belmont Stakes, two Kentucky Derbies, and the Preakness. He was a major rider in the metropolitan New York scene in the early 1890s. He rode for the Dwyer brothers and the Roncocas stable (Hotaling, 1889, 280-81, 287, 295-96, 308-09). He used very short stirrups, a high seat, and took a tight hold of his horse's head. According to the Chicago Daily News, "Simms is a perfect horseman, in spite of his unsightly seat, and displays great judgment, especially on horses that require coaxing and placing. He had beautiful hands, and is especially quick and clever in an emergency." (21 Apr. 1895, 6). 
first major instance of trouble for blacks in the racing business in New York occurred in 1894 when "the Colored Trust, a combination of negro trainers and owners of horse races, allied by negro jockeys, caused so much scandal by their gambling operation that the turf authorities were [forced to take action]." "Negro Jockeys Shut Out: Combination of White Riders to Bar Them From the Turf"). Then by the turn of the century, there was a dramatic, decline in black jockeys. In 1900 the Chicago Tribune attributed this to the ending of southern white prejudice against white riders because it was a job unfit for white men:

The colored boys, once so potent a factor in turf affairs are losing their grip [...]. With their departure goes one of the picturesque features of the turf-the laughing, happy, careless darkies that came off the Southern farms and into the public eye because of a natural inclination to ride. It is a curious fact, but colored boys are much more apt about a racing stable than white boys. They learn more quickly and get along better with their mounts, whether in exercise or actual racing. Any trainer will tell you that a midget of a negro will learn more about a table in a week than a white boy will learn in a month.

The black boys [...] they will work cheaper than the white boys, and they take to racing naturally. And, too, there at one time existed in the south, a strong prejudice against the employment of white boys in racing stables, a field of labor which was given over to the use of the negroes. That prejudice against the employment of white boys in racing stables, a field of labor which was given over to the use of the negroes. That prejudice kept the white boys in the corn fields while the black ones went on, learned to ride races, and became great money earners.

White owners were hiring whites as exercise boys which was a first step in becoming a jockey: "It takes longer to teach the white boy, but he is supposed to make a better article when he is completed [...] (1 Apr. 1900).

Some former African American jockeys tried to survive as owner/riders but most were limited to training and exercising. The renowned Willie Simms, by then over the hill, turned to training in 1902. White jockeys harassed many of the remaining black riders. The last great black jockey was Jimmy Winkfield, who won consecutive Kentucky Derbies in 1901 and 1902. He moved to France where he became a leading jockey for two decades, and then a successful trainer. The last well-known black rider was Jimmy Lee, "The Black Demon," who won four stakes in 1907 and six in 1908. On June 5, 1908 took all six races on one card, only third man to have done so. The last black to ride in the Kentucky Derby was Jess Conley in 1911, who came in third aboard Colston, named after African American trainer Raleigh Colston (Hotaling 1899, 280-81, 287, 295-96, 308-09; Hotaling 2004; Drape).

White jockeys were ganging up on black riders. According to racing historian Charles $\mathrm{B}$. Parmer, the decline of black riders started in jockey rooms when blacks got too cocky:

The white boys retaliated by ganging up against the black riders on the rails. A black boy would be pocketed, thrust back in a race; or his mount would be bumped out of contention on a white boy's stirrup, and toss him out of the saddle [...] those white fellows would slash out and cut the nearest Negro rider [...] they literally ran the black boys off the tracks." (Parmer 150).

The major reason for the decline in black ridership was racism among prominent horsemen like James Keene and jockeys. In the past turfmen had no problem using slave riders or later free blacks because they were still "servants" dressed in livery riding for their "master." Historian David Wiggins argues that the occupation was considered "nigger work" until the 1890s when the high salaries encouraged white riders to form "anti-colored unions" to drive out the black competition, raise the status 
of the occupation and keep the jockey positions for whites (Wiggins, 32; Hotaling 1995, 190-91).

The New York Times in 1904 credited the anti-black jockey union with playing an important role in pushing out black riders: "Whether the white jockeys devised the plan of a 'union' on their own behalf or whether they were advised by others has never come to light." The horse owners were willing to accept the new order. White jockeys cooperated to block off black jockeys to make sure they lost. The Times had no idea what caused the movement to force out black jockeys, but it obviously was racial prejudice and desire to get their lucrative jobs (29 July 1904, 14).

The discrimination in racing was identical to American racism writ large. Blacks were being forced out of skilled occupations (coachmen, barbers) and businesses (catering) because whites wanted those positions. This was also the case in sports, notably baseball, which had no African American major leaguers after 1884, and cycling, but less the case in the low status sport of prize fighting. Black boxers, like George Dixon and Joe Gans, continued to be prominent and even champions in the lighter weight classes, but still had limited opportunities, particularly in the heavier divisions, where they often could only get bouts against other blacks. Jack Johnson did win the heavyweight title in 1908, which only reinforced efforts to bar future black contenders from getting title shots (Logan, 357; Balf; Lanctot 2004; Riess 1999, 197-201; Wiggins 1997; Roberts 1985).

\section{The White Jockeys}

White riders were, like their black peers, largely drawn from impoverished backgrounds, and poorly educated. They were of small stature, starting out as apprentices at the age of fourteen, weighing less than seventy-five pounds. There were an enormous number of riders, 335 just in 1903, and most did not earn munificent incomes. They came from a wide variety of ethnic and geographic backgrounds, probably English in 1870s and 1880s and native white American and Irish backgrounds thereafter (Chicago Tribune, 13 Dec. 1903, 10; Hotaling 1995, 274).

The conventional wisdom was that riders were from rural backgrounds, and indeed, many were. However, jockeys were also products of major cities. For instance, Edward "Snapper" Garrison was born in New Haven, and through his work at a blacksmith job, learned to ride horses. Harry Griffin, a top rider in the 1890s, was born in New York City, and grew up in a Staten Island orphanage. Willie Knapp, the jockey of Exterminator and Upset (the only horse to defeat Man O'War) was from the North Side of Chicago. His father worked with horses at Hawthorne Racetrack, and his son became an exercise boy at ten, and a jockey at thirteen. Winnie Scott of Brooklyn, was the grandson of a member of the Brooklyn Jockey Club, and son of a broker who was a skating champion.

Among the top riders of the 1880s was Jimmy McLaughlin who rode for the Dwyer brothers, mainly in New York, capturing six Belmont Stakes (1882-1885, 1886-1888), which is still a record. He led jockeys in victories for seven times, and from 1882-1886, won 545 out of 1,498 races (36.4 percent). A member of the first group of inductees to the Racing Hall of Fame in 1955, he was not the most artistic rider ("His seat is rough and ungraceful",) but the most painstaking, and was compared to England's great Fred 
Archer. He was sparing with his whip, developed a keen judgment of pace and could ride a waiting race ("McLaughlin, James").

Even more prominent was Snapper Garrison, also an original selection into the Racing Hall of Fame. Garrison won over $\$ 2$ million in purses in the years 1880-1896, with over 700 victories, including the $\$ 50,000$ purse for the 1893 American Derby, held in conjunction with the World's Fair. Snapper was paid $\$ 23,500$ in 1894 by William C. Daley, the highest for any American jockey. He was noted for his "sobriety, pluck, determination in keeping his weight down, and thorough knowledge of his mounts." He was steady, courageous and was renowned for his great last section victories at the finish line, which became known as "Garrison finishes." According to the Chicago Daily News, "With his hands almost gripping the bit with his head pitched forward until he appears to be whispering in the mount's ears, Garrison's the jockey whose seat, style and methods are original" ("Garrison, Edward H."; Trenton Daily True American, 13 July 1891, 3; Chicago Daily News, 21 Apr. 1895, 6).

\section{Lightweight Riders}

One of the consistent problems in racing was the widespread use of lightweight jockeys, who were often inexperienced, physically weak apprentices. A weight scale adopted in 1876, which was lower than in England or Australia, permitted jockey clubs to hold races with jockeys weighing just $65 \mathrm{lbs}$. In 1882, jockeys could race as light as $74 \mathrm{lbs}$., compared to $84 \mathrm{lbs}$. in an Australian handicap. Such policies hampered the more experienced jockeys in getting rides while teenagers could make a lot of quick money. Grover Cleveland Fuller in 1902 earned $\$ 30$ a month as a stable boy. Less than a year later, riding at 91 to $100 \mathrm{lbs}$., he made $\$ 50,000$, equal to the American president. Fuller won nearly 300 races in just a year, including the Futurity, Suburban and Excelsior handicaps, winning $\$ 250,000$ in purses. He was originally on the first call to Tammany boss Big Tim Sullivan at a fee more than bank presidents earned and Frank Farrell paid nearly as much for his second call (Somers, 112; “Jockey Fuller's-From Obscurity to Prominence-Great Riding Record").

Turfmen worried this trend would damage their sport by producing poorer times and possibly endangering their high strung thoroughbreds. Furthermore, the health of the jockeys, always at risk because of their need to keep their weights low, became even more vulnerable. In 1890, for instance, Hayward, one of the preeminent American riders, got violently ill trying to get down to $110 \mathrm{lbs}$. for an important stakes race. English jockeys Wells and Tom French, and Australian Frank Butler succumbed to what was known as "hasty consumption" from reducing weight (Spirit of the Times 104, 25 Nov.1882, 480; 110, 25 April 1885, 392; 122, 10 Jan. 1891, 996).

There were frequent calls to raise the weight scale to deal with the lightweight nuisance and boy-jockey monopoly that helped ruin more horses than all other causes combined. The Spirit consistently criticized the lightweight system, and wondered if those riders are just along for the ride. A major article in 1895 blamed many racing problems on inexperienced lightweights, such as the problem of getting horses away on time or in an orderly fashion, very difficult before mechanical starters were used. The Spirit blamed the problem on

light, inexperienced boys who lack both the ability and the physical strength to handle heavy-handed or fractious horses at the post [...]. Boys of this class are so 
small and so deficient in strength that they only way they can make any impression on a horse is by digging their heels into his sides. [...] With three or four such boys riding in a race it is almost impossible for any starter to get the horses in position for a good send-off (Spirit of the Times 129, 5 Sept 1895, 394).

The weight advantage was so important that even superstar jockeys like Fred Taral, who rode at 112-lbs. had trouble getting mounts outside of the big stakes events. The Spirit felt that most mounts should go to veteran jockeys: "With the vast majority of the lightweight stable boys now riding, the issue of a race between them is a matter almost entirely of luck. It is a case of which one gets away in front and has plain sailing after the start is effected" (Spirit of the Times 129, 5 Sept. 1895, 394).

The Chicago Tribune castigated this arrangement as a "padrone system": Manipulated by this or that man, and trafficked around like the slaves in the South [...], what wonder is it that our ruling talent is demoralized? What wonder that many whose very God seemed to have deigned them for jockeys by the diminutive stature he gave them, are standing on the ground idle, or seeking engagements on foreign shores?" (13 Dec. 1903, 10).

The Spirit took trainers to task for allowing this situation to fester. One of the worst cases was at Chicago's Harlem track, which hosted the Owners' Handicap, a one mile that drew four midget riders, including 11 year-old Willie Dorsey (47 lbs.) in his first race (Spirit of the Times 134, 9 Oct. 1897, 324).

The weight issue was important in shaping the behavior of jockeys who constantly struggled to maintain themselves at $112 \mathrm{lbs}$. or less, and sometimes ended up being ruined physically and mentally. Star jockeys had a hard time lasting. Historian Wray Vamplew found in England that in 1920, 140 of 317 (44.2 percent) licensed jockeys rode four or less years, and 193 (60.9 percent) eight or less. The tendency to grow heavier was a huge factor causing riders to retire (Vamplew 1976, 170; New York Times, 29 Nov. 1903, 14).

40 The Chicago Tribune claimed the system discouraged the recruitment of honest rural youth, who were too fit to make the low weight requirements. Instead, apprentices were drawn from the ranks of street urchins who were malnourished, frail, and morally weak. Every day a horse lost just because his jockey was physically weak, and each week some rider was ruled off "because he had not strength of mind sufficient to resist the specious affronts of some turf parasite" (19 Feb. 1900, 4).

One of the top lightweights ever was Walter Miller, an Orthodox Jewish lad from New York City who was the most outstanding teenage jockey riding at less than $90 \mathrm{lbs}$. Turf writer Sam Elias described Miller as "a better rider than Tod Sloan." He won his first races at just fourteen, including a 60-1 shot. He achieved his greatest glory riding for James R. Keene's renowned stable. In 1906, Walter won 388 out of 1384 races (28 percent), when 500 races was considered a busy season. His record victories were not even tied until 1950. From 1905 to 1909, Miller won 25.2 percent of his 1,094 races. He was particularly well known as a jockey who got quick starts from his horses by keeping them calm, and getting away from the traffic. Miller's career was brief because he grew to 5' 8.5" and 160 lbs. Like McLaughlin and Garrison, he was an original member of the Racing Hall of Fame ("Lightweight Jockeys Take Place as Stars;" Postal, Silver, and Silver, 320-22). 


\section{American Jockeys in England}

42 At the turn of the century, the presence of outstanding American jockeys in England achieving unprecedented success, turned English racing upside down, and generated enormous resentment by local racing folk. The first major American rider in England was Willie Simms, the outstanding African American rider. In 1895 Boss Richard Croker of Tammany Hall took him to England where he raced for four months. Experts anticipated that Simms's style of riding would create a little sensation in England. He used very short stirrups, a high seat, and took a tight hold of his horse's head. Simms was mocked by the English as "the monkey on a stick," and not credited for his "welljudged generalship in a race." He won the Crawford Plate on Croker's Eau Gallie to become the first American to win in England aboard an American owned and trained horse ("Simms, Willie"; Chicago Daily News, 21 Apr. 1895, 6; Spirit of the Times 140, Sept. $22,1900,284)$.

The successful American invasion really began with the arrival of Tod Sloan, the most famous jockey in the world. He hobnobbed with celebrities, and was the model for "Yankee Doodle" in George M. Cohan's Little Johnny Jones. Tod was born near Kokomo, IN. He attended school briefly, was the product of a dysfunctional family (his mother died when he was five), and was on his own from age thirteen. He was nicknamed "Toad" as a child because of his diminutive size, and through racing, became a prince. Sloan popularized the style of riding made popular by Snapper Garrison (which Simms probably originated), in which the jockey laid along the neck and shoulders of his horse which gave him more control over his mounts and cut wind resistance. Tod had several excellent years riding in the United States, and became the principal rider for William C. Whitney, who owned the leading American stable. He was brought over to England in 1896 by James Keene, and in 1897 rode for Pierre Lorillard, achieving particular success in dashes with his quick starts. That autumn, Sloan made over 2,000 pounds (after expenses), winning on 20 of 53 rides. In 1898, Sloan rode for Lorillard and Lord William Beresford, and the Prince of Wales, capturing 43 of 78 races in the autumn, and 46 percent for the entire year. One year later Lord Beresford paid $£ 5,000$ for his first services. He spent a full season in England, winning 108 and coming in second 103 times out of 345 events (New York Times, 22 Dec. 1933, 21; The Times (London), 22 Dec. 1933; Sloan 1915, 1-5; Dizikes, 2000; Vamplew 1976, 52-53).

As the Chicago Tribune noted, "When the Englishmen saw Sloan their scorn of his style inflated them to the bursting point almost. Their guffaws could be heard on this side of the Atlantic. Their critics likened his position in the saddle to that of a monkey on a stick." But within a few weeks, he made the best English jockeys look like novices.

He obliterated riding theories that had been cherished for more than a century, and his many and brilliant successes were the talk of all England. Sloan was the pioneer of an invasion that in the realm of peaceful endeavor was one of the most remarkable witnessed in this century just closed. To have gone into the home of the thoroughbred and among horsemen who had a calm and impregnable faith that they were the master horsemen of the world, and to have humbled them, to have turned their scorn into envy, surely was a victory well worth the winning (22 Dec. 1901, 20).

His success created a demand for American jockeys all over the continent (Spirit of the Times 140, 1 Dec. 1900, 479). 


\section{historian Wray Vamplew, was equivalent to a 10-14 lb. weight advantage compared to the English hunting style in which the rider rode erect, straight kneed, and a long rein. However, the English still felt their men would win a tight race by their superior control of the animal. But Vamplew points out that American tried to avoid that circumstance by going to the front well before the winning pole. The old waiting race style lost out to the more aggressive Americans. The Americans were better judges of pace, with more experience in riding to the clock. Vamplew also argues that the introduction of the starting gate in Great Britain in 1897 also helped because Americans were already familiar with mechanical starts (Vamplew 1976, 54-55; Spirit of the Times 149, Sept. 22, 1900, 284).}

lessened wind resistance and better distributed the rider's weight, which according to

47 Johnny Reiff. The former went to England because he had gotten too heavy to get enough rides in the USA, but his midget brother, who was considered among the top lightweight (90 lbs.) riders of all-time, had no such problem. American trainers Duke and Wishard were instrumental in bringing them to England where they rode for Richard Croker. They showed that it was not just Sloan's ability, but the American style of riding that was winning the races ("The American Jockey Invasion").

The American domination in England was remarkable. In 1901 Lester Reiff took the Derby on W.C. Whitney's Volodyovski, and Americans won the race five times in six years (including three wins by Danny Maher). From 1896 to 1901, an English rider only topped the best American percentage in 1899. In 1900 and 1903 half of the top ten jockeys were Americans. Sloan in 1900 won nearly 27 percent of his races, while Lester Reiff won 26 percent, and Maher, Skeets Martin, and Johnny Reiff all surpassed 20 percent. One year later L. Reiff had 23 percent, Maher 33 percent, McCall, the Englishman 20 percent, and Johnny Reiff, 18 percent. The result, noted the Spirit, was "that English jockeys had become exceedingly doleful with the conviction that they were to be swept practically out of existence" ("The American Jockey Invasion"; Spirit of the Times 142, 28 Dec. 1901, 1034).

American jockeys were also doing well elsewhere. In 1901 an American was the leading rider in England (Danny Maher), Russia (Cass Sloan), and Austria-Hungary (Fred Taral). Other stars included Peter Freeman in France and Eddie Ross and Nate Hill in Germany. As the Chicago Tribune recognized, "It seems to be only yesterday that the American jockey and the American style of riding were the laughing stock of the horsemen of England and the continent. Now the American jockey and the American style of riding are the wonder, if not the admiration of the world, and in every clime the American jockey is sought after as the most valuable of turf possessions." American jockeys in England and on the continent earned about $\$ 150,000$, led by Lester Reiff, with $\$ 30,000$, including Whitney's retainer fee at least $\$ 15,000$. Maher was second with $\$ 25,000$; Johnny Reiff, \$15,000; and Cass Sloan \$12,000 (22 Dec. 1901, 20). The English racing establishment was very jealous of the American performance. The English Jockey Club was very suspicious of the American success, and several were often suspended. Vamplew assets that "Some of this was due to the difficulties of keeping straight when riding with the American seat, but much was attributable to sheer dishonesty and disregard for the rules of racing." In October 1901, Lord Durham 
charged the reigning champion rider Lester Reiff, of pulling a horse, and he was banned from the English turf (Vamplew, 1976, 57; Spirit of the Times 142, 23 Nov. 1901, 910.

Earlier that year, Tod Sloan's career came to an abrupt end when the English Jockey Club refused to renew his license. They claimed his betting, which was an open secret, his connections with nefarious gamblers, and other actions, were detrimental to the sport, but never made public detailed particulars. At an inquiry after the 1900 Cambridgeshire, Sloan claimed that all jockeys bet. He had bet 2,000 pounds on his own horse, which was commonplace in the USA. In addition, sloan admitted that he had been promised an expensive present if he won from a professional gambler. Furthermore, the Prince of Wales had offered Sloan 6,000 pounds to ride for him. But Edward broke off the contract talks when he became king in 1901, naturally raising eyebrows. According to Vamplew, Sloan condemned himself by his vanity, stupidity, love of gambling, and choice of friends that made him persona non grata with the EJC, which intimated he not bother applying for a new license. The Spirit pointed out that although Sloan was the jockey of the century, and totally honest, he had tried to rise above his place in the social structure, behaving as he pleased, and not giving due deference to the men who ran the sport. It blamed him for not knowing the local rules and customs (Vamplew 1976, 56-57; Spirit of the Times 140, 15 Dec. 1900, 530).

Powerful friends tried to help him restore his reputation, but Sloan never regained his license and was banned from racing at all major tracks around the world, although he was allowed to enter his own horses in races and make bets. He reputedly earned about $\$ 300,000$ during his career, including $\$ 50,000$ in just one racing season, but lived a profligate life, and ended up broke ("Sloan, Tod").

In due course, the British learned from the Americans, and developed a modified American seat and dropped the waiting style. They rode with shorter stirrups, but did not hold the reins so loosely or ride atop the withers of their horses. Their new technique was very good for their undulating courses. Consequently, the British fended off the invaders, except for Maher, who had learned to modify his own style of riding. He won 25.3 percent of his races between 1900 and 1914 (1,331 winners), and remained in Great Britain for the rest of his career. Despite his shortened career, he was elected to the Racing Hall of Fame in 1955 (Vamplew 1976, 58; Sloan, 106-25).

\section{Conclusion}

Since the 1880s, the occupation of the jockey was extremely lucrative for men at the head of their profession, and top jockeys earned more than any other professional athletes. The job in the late nineteenth century was among the most democratic and meritocratic occupations, open to all short, light weight talented male riders in the late nineteenth century. The occupation had a significant proportion of African Americans at its highest levels, which was very unusual in the United States, especially for a high paying occupation.

However, as the sport became even higher paying, the number of jobs became fewer and fewer because of the declining numbers of high class tracks in operation. Racism in and of itself was sufficient in dramatically altering recruitment patterns and the hiring process, as it did in all occupations where blacks had been successful. This was further exacerbated by the declining business. Thoroughbred owners responded to the declining opportunities to race by decreasing the size of their stables, getting out of the 
business, or looking for opportunities abroad. Many of the top jockeys followed the stables to England.

Racing horses was an extremely dangerous job, and even the most successful jockeys had a hard life that required great privation to "make weight." Not surprisingly, their work encouraged riders on their off time to live for the moment. The top jockeys enjoyed a lot of fame, hobnobbed with celebrities, and made a lot of money. However, they spent their money as fast as they made it (not unusual given their social backgrounds and the danger of their career), and had little training for a career off the turf when that time came.

\section{BIBLIOGRAPHIE}

ADELMAN, Melvin L., A Sporting Time: New York City and the Rise of Modern Athletics, 1820-70, Urbana, University of Illinois Press, 1986.

“All the Best Jockeys of the West are Colored," Spirit of the Times 119, 7 June 1890, 1.

“The American Jockey Invasion,” Badminton Magazine 24, April 1907, 429.

American National Biography, s.v., "Sloan, Tod."

ASHE, Arthur R., Jr., A Hard Road to Glory: A History of the American-American Athlete, 1619-1918, New York, Warner, 1988.

BALF, Todd, Major: a Black Athlete, a White Era, and the Fight to be the World's Fastest Human Being, New York, Crown, 2008.

CASE, Carole Down, The Backstretch: Racing and the American Dream, Philadelphia, Temple University Press, 1991.

DIZIKES, John, Yankee Doodle Dandy: The Life and Times of Tod Sloan, New Haven, Yale University Press, 2008.

“English Racing Notes," Spirit of the Times 140, 1 Dec. 1900, 479.

DRAPE, Joe, Black Maestro: The Epic Life of an American Legend, New York, Harper Collins, 2006.

"Garrison, Edward H," in Biographical Dictionary of American Sports, vol. 4, Outdoor Sports, David L. Porter, ed., New York, Greenwood Press, 1988.

“Great Nerve Required in Many Cases by Winning Jockeys," National Police Gazette, Sept. 2, 1905, 6. GRUENDER, Scott A., Jockey: The Rider's Life in American Thoroughbred Racing, Jefferson, NC, McFarland, 2007.

"Hard Work of a Jockey," Chicago Daily News, 13 June 1893, 6.

HERVEY, John, Racing in America, 1665-1865, 2 vols., New York, The Jockey Club, 1944.

HOTALING, Edward, Wink: The Incredible Life and Epic Journey of Jimmy Winkfield, Camden, Me, McGraw-Hill, 2005. 
---, The Great Black Jockeys: The Lives and Times of the Men Who Dominated America's First National Sport, Rocklin, CA, Forum, 1999.

---, They're Off! Horse Racing at Saratoga, Syracuse, Syracuse University Press, 1995.

“The Influx of Foreign Jockeys and Its Results," Spirit of the Times 140, 1 Dec. 1900, 479.

“Jockey Fuller's-From Obscurity to Prominence-Great Riding Record," National Police Gazette 83, Oct. 17, 1903, 3.

“A Jockey Ring in England," Spirit of the Times 120, 10 Jan. 1891, 996.

LANCTOT, Neil, Negro League Baseball: The Rise and Ruin of a Black Institution, Philadelphia, University of Pennsylvania Press, 2004.

“Lightweight Jockeys Take Place as Stars," New York Times, 10 Dec. 1905, 12

LOGAN, Rayford, The Betrayal of the Negro, New York, Collier, 1965.

“McLaughlin, James," in Biographical Dictionary of American Sports, vol. 4, Outdoor Sports, David L. Porter, ed., New York, Greenwood Press, 1988.

"Negro Jockeys Shut Out: Combination of White Riders to Bar Them From the Turf," New York Times, 29 July 1904, 14.

PARMER, Charles P., For Gold and Glory: The Story of Thoroughbred Racing in America, New York, Carrick and Evans, 1939.

POSTAL, Bernard, Jesse Silver, and Roy Silver, Encyclopedia of Jews in Sports, New York, Bloch, 1966.

REILLEY, Kellie “Ben Brush - 1896 Kentucky Derby winner,” The Handicapper's Edge, http:// www.brisnet.com/cgi-bin/editorial/article.cgi?id=4245 (accessed 21 January 2010).

RIESS, Steven A., Touching Base: Professional Baseball and American Culture in the Progressive Era, rev. ed., Urbana, University of Illinois Press, 1999.

---, “A Social Profile of the Professional Football Player, 1920-1980," in Paul Staudohar and J. A. Mangan, eds., American Professional Sports: Social, Historical, Economic and Legal Aspects, Urbana, University of Illinois Press, 1991, 222-46.

---, "Sport and Social Mobility: American Myth or Reality," in Donald G. Kyle and Gary Stark, eds., Essays on Sport History and Sport Mythology, 83-117, College Station, Texas A\&M University Press, 1990.

---, "Professional Baseball as an Avenue of Social Mobility," Journal of Interdisciplinary History 11, 1980, 235-50.

ROBERTS, Randy, Papa Jack: Jack Johnson and the Era of White Hopes, New York, Free Press, 1985.

ROBERTSON, William H. P., The History of Thoroughbred Racing in America, Englewood Cliffs, NJ, Bonanza Books, 1964.

SCOTT, Marvin B., The Racing Game, Chicago, Aldine, 1968.

"Simms, Willie," in Biographical Dictionary of American Sports, vol. 4, Outdoor Sports, David L. Porter, ed., New York, Greenwood Press, 1988.

"Sloan, Tod," in American National Biography, John A. Garraty, Mark C. Carnes, eds., New York, Oxford University Press, 1999.

SOMERS, Dale, The Rise of Sports in New Orleans, 1850-1900, Baton Rouge, Louisiana State University Press, 1972. 
Spirit of the Times 112, 8 Jan. 1887, 738.

Spirit of the Times, 113, June 25, 1887, 729.

SUGAR, Bert, and Cornell RICHARDSON, Horse Sense: An Inside Look at the Sport of Kings, Hoboken, NJ, John Wiley and Sons, 2003.

SLOAN, Tod, Tod Sloan By Himself, ed. by A. Dick Luckman, London, Grant Richards, 1915.

"Successful Jockeys Reach the Top by Hard Work and Energy," National Police Gazette 83, 4 July 1903, 6.

TARELTON, L. P., “A Memorial,” Thoroughbred Record, 21 Mar. 1896, 136.

Trenton Daily True American, 4 June 1890.

TREVATHAN, Charles E., “Too Much Foul Riding,” Chicago Tribune, 19 March 1900.

VAMPLEW, Wray, "Sporting Innovation: The American Invasion of the British Turf and Links, 1895-1905," Sport History Review 35:2, Nov. 2004, 122-37.

---, "Still Crazy after All Those Years: Continuity in a Changing Labour Market for Professional Jockeys," Contemporary British History 14:2, 2000, 115-45.

---, The Turf: A Social and Economic History of Horse Racing, London, Allen Lane, 1976.

VOSBURGH, W. S., Racing in America, 1866-1921, New York, The Jockey Club, 1922.

WIGGINS, David K., "Isaac Murphy: Black Hero in Nineteenth-Century American Sport,

1861-1894," in David K. Wiggins, Glory Bound: Black Athletes in White America, Syracuse, Syracuse University Press, 1997, 21-33.

\section{RÉSUMÉS}

American jockeys for most of the nineteenth century were African Americans. It was a dangerous occupation that paid extremely well for successful jockeys. These riders were pushed out of this occupation, as jockeys became recognized as important factors in racing results and as it became increasingly lucrative, just as they were pushed out of other desirable jobs in the era of Jim Crow.

\section{AUTEUR}

\section{STEVEN A. RIESS}

Northeastern Illinois University 